\title{
New Jurassic Play Concepts in the Mesopotamian Basin and the Western Desert of Iraq
}

\author{
Ahmed Asker Najaf Al Ahmed \\ Faculty of Science, University of Al Nahrain, Jadriya, Baghdad-Iraq. \\ E-mail: drahmedaskar@yahoo.com.
}

\section{Abstract}

Intensive tectonic activity during Zagros Orogeny (Late Cretaceous-Late Tertiary) and the final uplift in Holocene, reactivated folds and faults and eroded parts of the Lower Cretaceous, Jurassic and earlier sequences in western Iraq. Subsequently, within the Study area, the post Jurassic tectonics and the Upper Jurassic paleo-depositional environments left potential carbonate reservoirs at the basin margin (the Najmah Formation) and a potential evaporite cap rock (the Gotnia Formation) basin wards. Such relationship sealed the generated hydrocarbons from the source rocks formations (the Sargelu Formation) but it unlikely sealed the laterally migrated oil into the Najmah Formation. The major N-S fault planes of the Khleisia uplift that extended from northwestern part of Iraq to the southwestern Desert forming a barrier to laterally migrated oil and putting an end to the potential migration pathways from the Basinal Sargelu Formation in ENE Iraq. At the same time the prolonged thermal activity may have convert the organic matters within Paleozoic layers to Thermogenic gases.

Total petroleum system enabled us to better understand the provenance of oil accumulated in the Najmah Formation's layers another rock packages. According to 1-dimention model the migrated oil can pass through the Khleisia fault planes into the Middle Jurassic Muhaiwir Carbonate Formation (marginal equivalent to basinal Sargelu Formation) to form potential oil reservoir sealed by Gotnia evaporates and Kimmeridgian anhydrite .The equivalent formations located in western desert (Ubaid, Hussiniyat and Amij) Formations to the formations located in the central part (Mesopotamian Basin) which is (Butmah, Adaya, Mus and Alan Anhydrite) may consider as a new Jurassic reservoirs. So far no oil wells yet are available to cover the study of the whole area.

Keywords: Jurassic, Formation, Reservoir rocks, Migration, Mesopotamian Basin, Zagros fold belt

\section{Introduction}

Iraq considers as a promising area to generate theromgenic gas and reserves the migrated oil through the potential pathways from the eastern part of Iraq.

Najmah Formation of Malimain age represents calcareous neritic and lagoonal facies of the upper Jurassic period in Iraq overlaying major unconformity that could trap oil. The presence of Gotnia Formation which is consists of $(200 \mathrm{~m})$ of anhydrite with subordinate shale and limestone appear to be a tight seal for local oil and gas accumulation in underlying Najmah limestone and oil in interbedded limestone, Al Sharhan (1997).

Muhaiwir Formation equivalent to Sargelu Formation (Middle Jurassic), a which is may also considered as a potential reservoir rocks, and generally.

Lower Jurassic formations (Ubaid, Hussainiyat and Amij) in western Desert seem to be typical formations to correlate with the central parts (Mesopotamian Basin).

Accordingly, Iraq may reserve supergiant reservoir as extension of thick oil prone of source rocks with excellent seals from Ordovician to Tertiary (Al Jobouri, 1979, USGS, 2004) in addition to the current announcement of the Iraqi Ministry of Oil that refers to have 505 Trillion cubic meter of reserved oil in Iraqi super giant fields.

Considered as a major control of the of clastic reservoir properties, which reserves the horizontally migrated oil from nearby Sargelu Formation (Pitman, et al, 2004).

Geophysical prospecting via seismic section already contributes in recognizing remarkable geological structure (folds and faults) that characterize the active tectonic history of the Mesopotamian Basin, located within the succession of the subsurface 
formations of the western desert along Wadi Horan as shown in the map (Fig.(1)).

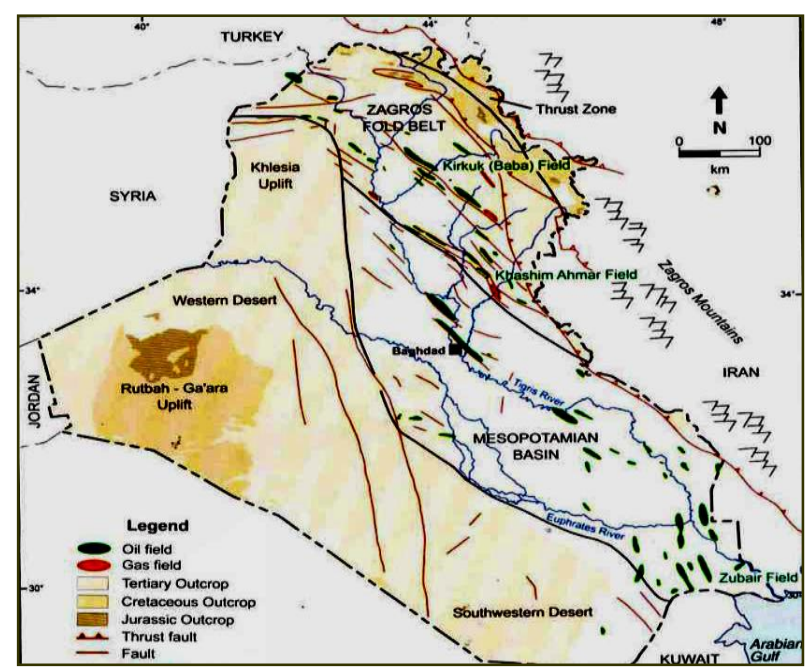

Fig.(1) Map shows location of the Mesopotamian basin and the Zagros Fold belt and major oil and gas fields modified from Aqrawi, 1998). (Pitman, 2004).

\section{Geological Setting}

The area of study include wide areas of promising to reserve hydrocarbons which surrounds western part of Zagros Fold Belt (Mesopotamian Foredeep) in central faulting zone (Ditmar,et al, 1972), and geosynclinals flank Fig.(2) ,and Mesozoic stable shelf (khlesia Uplift).

The structural evolution of the Zagros Fold Belt reflected in the orientation of present structures. The structurally complex Zagros Fold Belt is characterized by a liner NW-SE folds and fault pattern that was imposed during Palogene and Neogene tectonism.

The present seismcity indicates that Zagros fold belt is still tectonically active (Jackson et al 1984), (Hessami et al 2001). The development during the lower-Middle Jurassic sub stage of the upper Triassic-Middle Jurassic cycle started with a progressive transgression on the Stable Shelf where the Triassic and Jurassic were separated by a break after the Rhaetic emergence.

On the remaining, mobile areas the emergence and transgression are marked by terrigenous clastic supply or by increased subsidence only. Lagoonal evaportic facies throughout liassic decreasing toward north east, abrupt change in the sedimentary regime during Middle Jurassic took place. Transgressing of the sea includes stable shelf toward west and southwest with the late Liassic occurred in the geosynclines in Iran (stocklin, 1968). The former basin during Liassic which is partly or fully with evaportic sedimentation was replaced by a neritic euxinic one and the area of the former continent are of shallow water, littorallacustrine sedimentation was replaced by aneritic calcareous-pelitic or calcareousarenaceous sedimentation.

At the end of the Doggerian a regressive phase marks the end of the cycle (Buday, 1980).

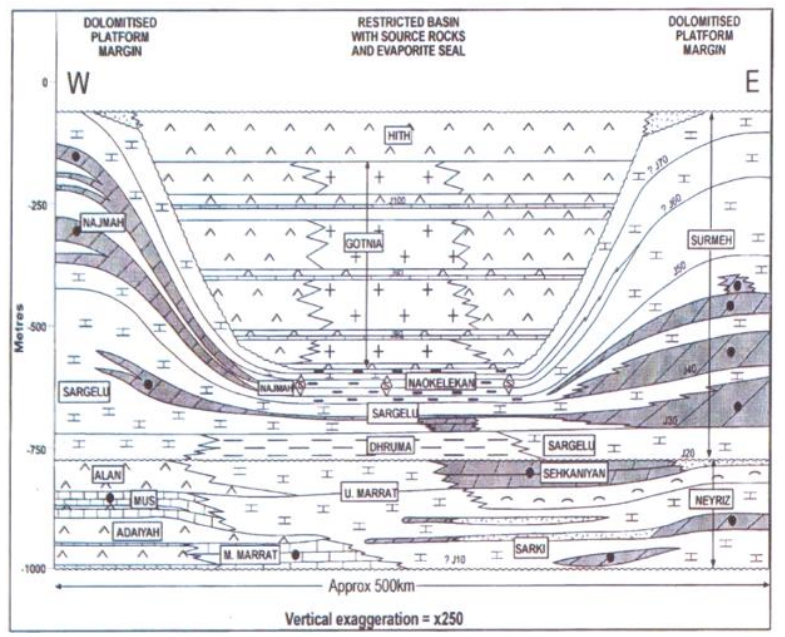

\section{Fig.(2) Stratigrphic correlation section through the Jurassic sequences of the Gotnia Basin.}

\section{Geophysical Indication}

Primary accumulation in Jurassic reservoirs could determined through recent secondary accumulation due to certain evidences like the exist of up dip migration from source beds toward the western part of Iraqi land, meantime Kimeridgian anhydrite forming seal rocks, in addition to other minor faults abundant around this area (Fig.(3)) also indicates secondary accumulation in upper Jurassic reservoir .These accumulations are mainly formed nearby the most important source rocks that generates oil and gas then trapped, close around the unstable zone which already forms due to the tectonic activity (orogenic movement) so a liner folds as shown in seismic sections is with out doubt traps the Still generates oil and gas. 


\section{Fault properties:}

Depending on seismic section, already available in the reports of oil well, (Fig.(4)) and structural schematic section shows high amplitude normal faults were defined as Semisealing in the horizontal direction, and semiopen in the vertical direction. The property of this faults permitted cross-formation flow in the model, while allow for trapping petroleum in a vertical succession of reservoirs.

It should be noted that only major fault zones in Zagros Fold Belt were incorporated in the regional model. Thrusting in the Zagros Fold Belt is trending NW-SE crossing North eastern Iraq which uplifted the subsurface section to form outcrop for the Sargelu Formation as an effect of tectonic compression that may indicate intensive minor faults affect by one way or another to the migration of oil. So it isn't easy to determine all the faults meanwhile the area described as an imbricate zone.

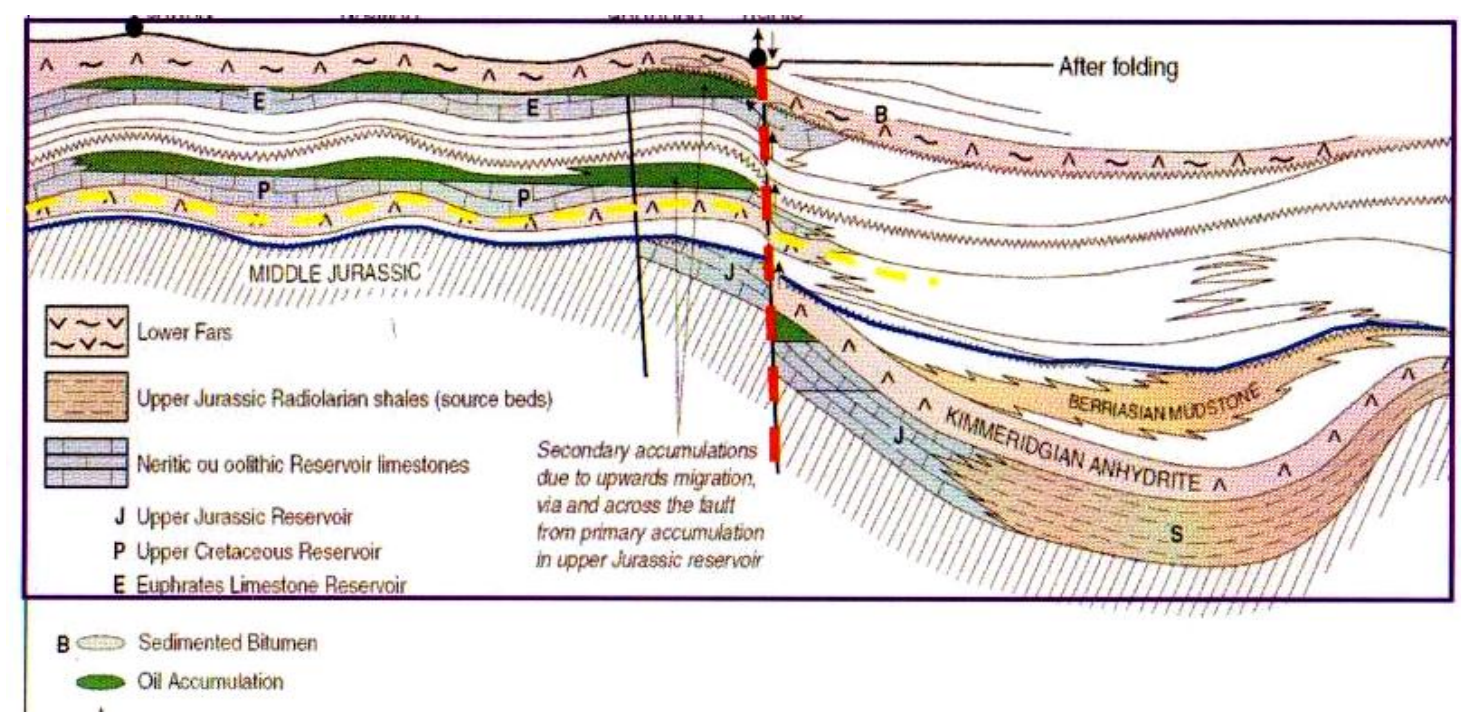

Fig.(3) Schematic sections across the studied area illustrating the probable mode of accumulation of oils in Jurassic, cretaceous and Tertiary rocks.

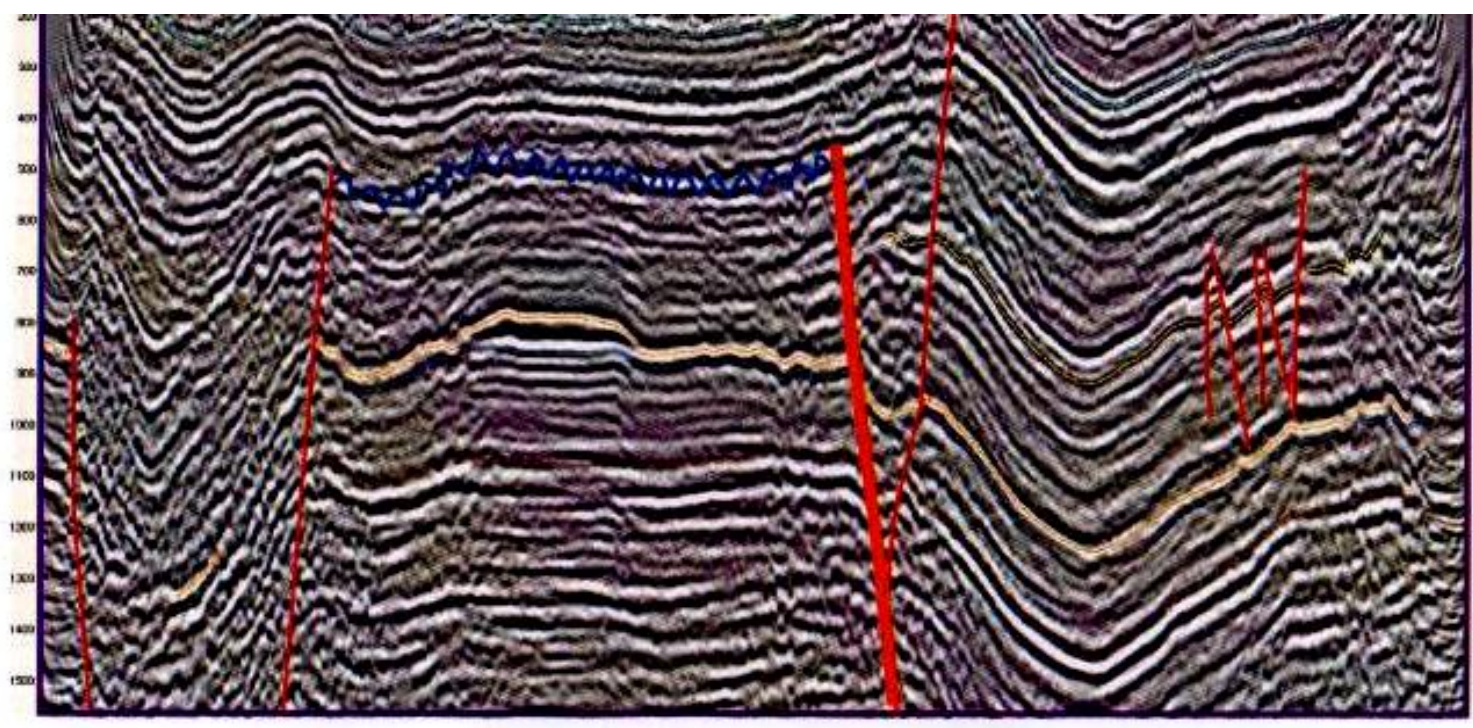

Fig.(4) Seismic section shows folding and faulting that trapping oil due to tectonic activity. 


\section{The predicted Clusters:}

\section{1- Najmah Formation;}

Geochemical analysis referred to this formation as being formed from dolomite especially in borehole (KH12/7) situated about $50 \mathrm{~km}$ away from Anah city in the west Iraq, but its outcrop is in Wadi Horan within Western Desert consists mainly from limestone (Jamil, et al,1994). The previous indications shown high effect of dolomitization and increasing in noncarbonate content in section downwards (Basssi et al, 1988). Plate-1 show bioclastic Oolitic Packstone-Wackstone facies and peloidal Packstone (Jamil, 1994). In general this type of lithology may consider as the typical reservoir rocks located in western part of Iraq.

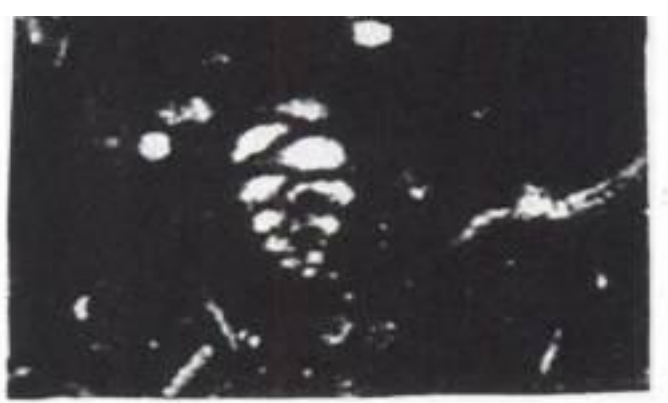

2

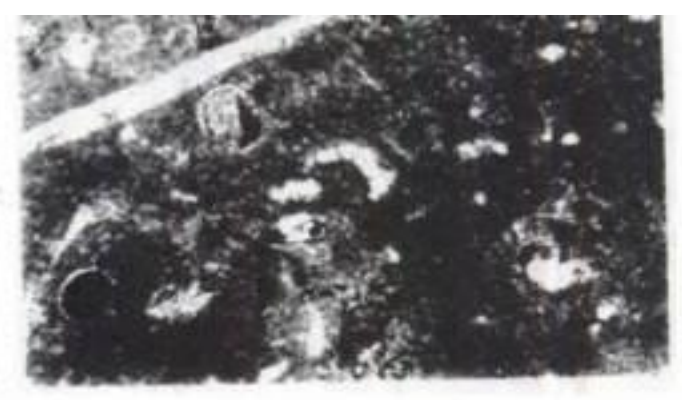

1

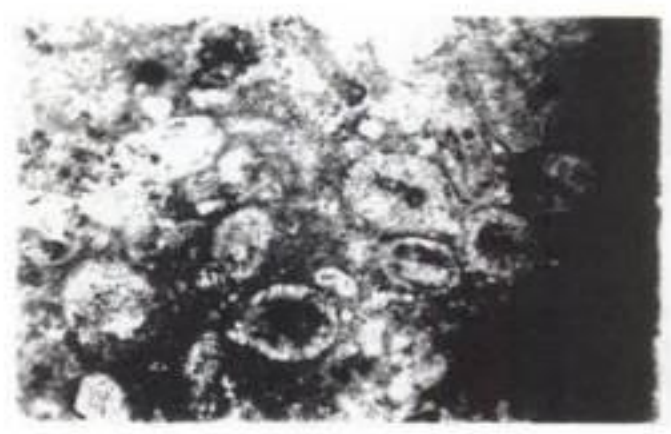

3

Plate -1 (1\&2) is Bioclastic Oolitic Packstone -Wackstone Facies, and (3) is peloidal Packstone (Jamil et al, 1994).

\section{2-Muhaiwir Formation}

This formation consists mainly from, sandy, Oolitic, profusely spicular, neritic limestone with full open -sea fauna. (Bellen et al, 1958).

The expelled oil from Sargelu Formation might inject horizontally through this formation in spite of the abundances of the fault planes that faced the route of migrated oil with subordinate gas tonguing and isochronously bounded with Sargelu Formation may forms remarkable reservoir Fig.(5). 

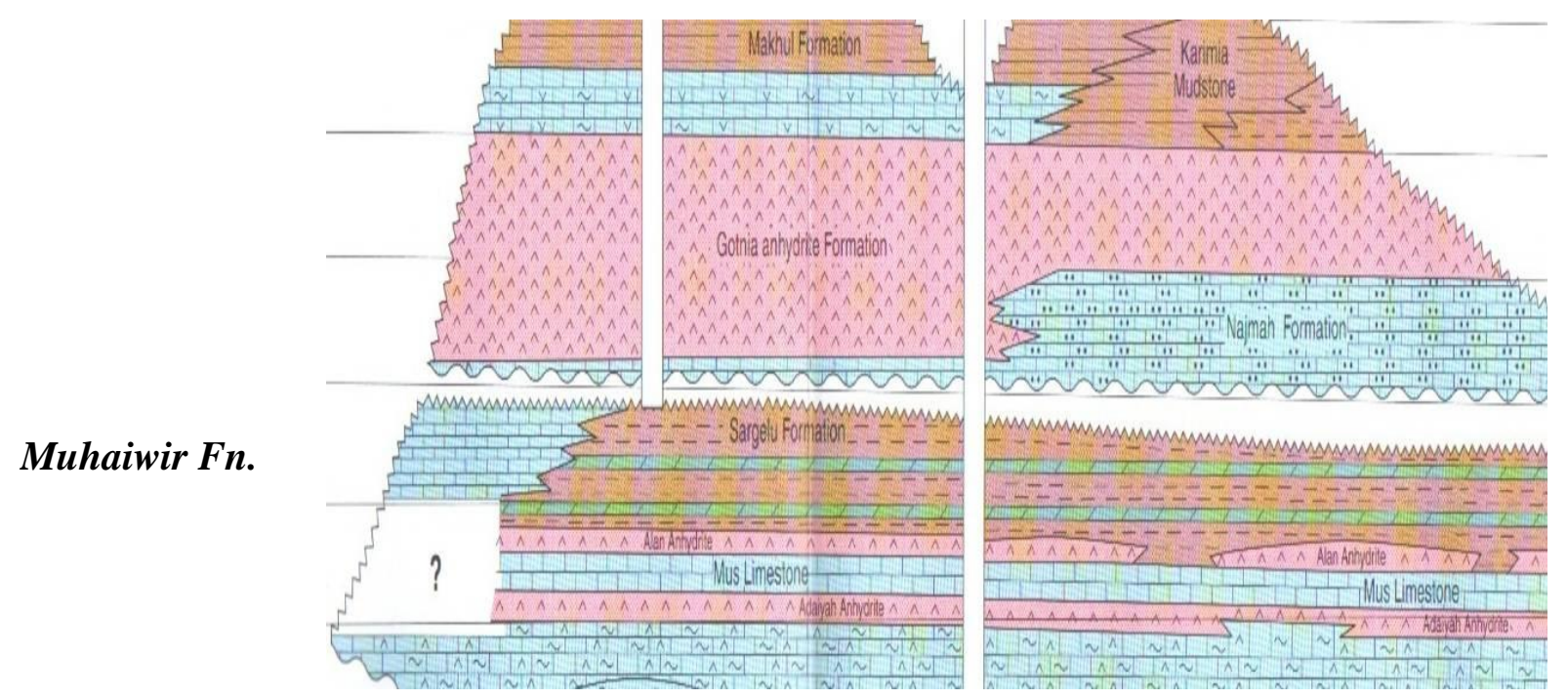

Fig.(5) Geologic section shows the promising formation to reserve oil in addition to gap and source rocks (Lexique).

\section{The Equivalent clusters:}

The Lower Jurassic (Liassic) formations located and exposed in Western desert are graded laterally to central part of Iraq (unstable shelf) into Butmah- Adaya-Mus-and Alan anhydrite Formations, so the equivalent formations as follows enabled to do comparison and correlate well with the lithofacies mainly consist of Dolomiticpeloidal packstone and Oolitic grainstones might consider as a typical and reliable reservoirs. These variations lead to conclude that the upward migrated oil from both

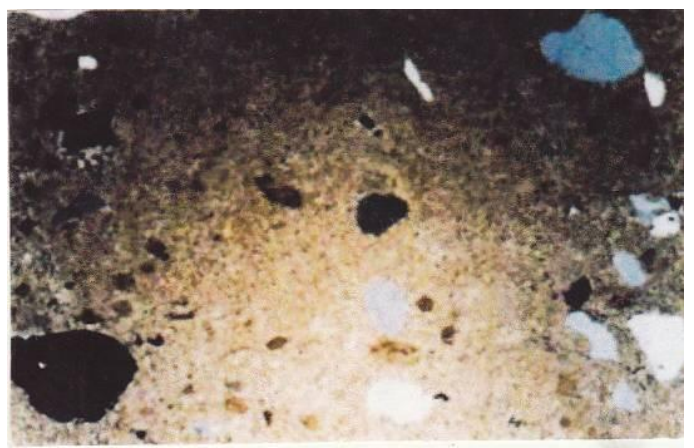

(1)
Triassic and Paleozoic rocks could trapped in these equivalent clusters.

\section{1- Ubaid Formation:}

Is the oldest exposed formation .Jurassic (Liassic) in the stable shelf of western Iraq I desert (Stable Shelf), which deposited in various environments within the carbonate shelf .This formation consists of dolomitize mudstone with some sand grains (plate-2 no. 1), dolomitic bioclastic wackstone and dolomitic peloidal packstone (plate-2 no.2\&3).

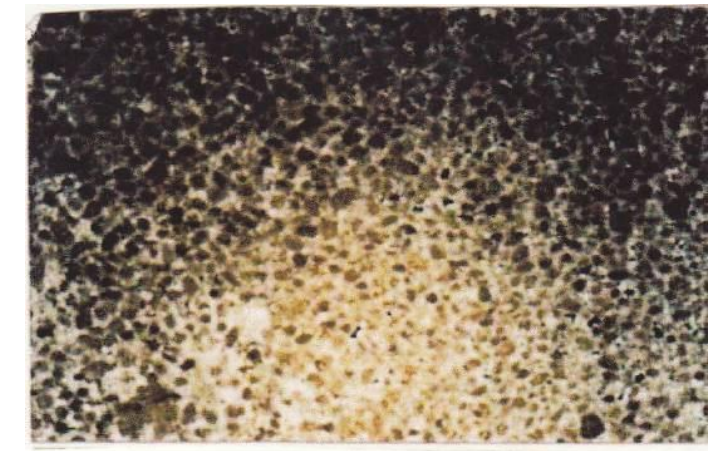

(2)

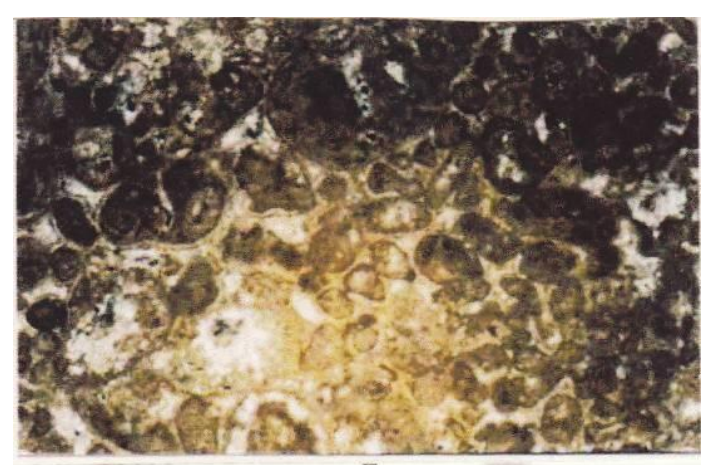

(3)

Plate- 2 lithofacies of Ubaid Formation (Mag.x10). 


\section{2-Hussiniyat Formation:}

This formation is composed of two major units, Lower clastic unit and upper carbonate unit. Microfacies analysis of the carbonate unit represented by dolomitic peloidal

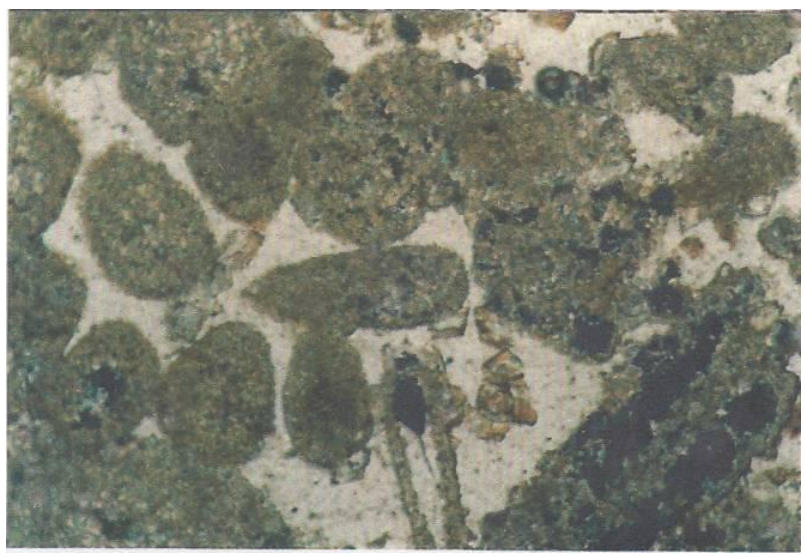

(1) Mag.x 40

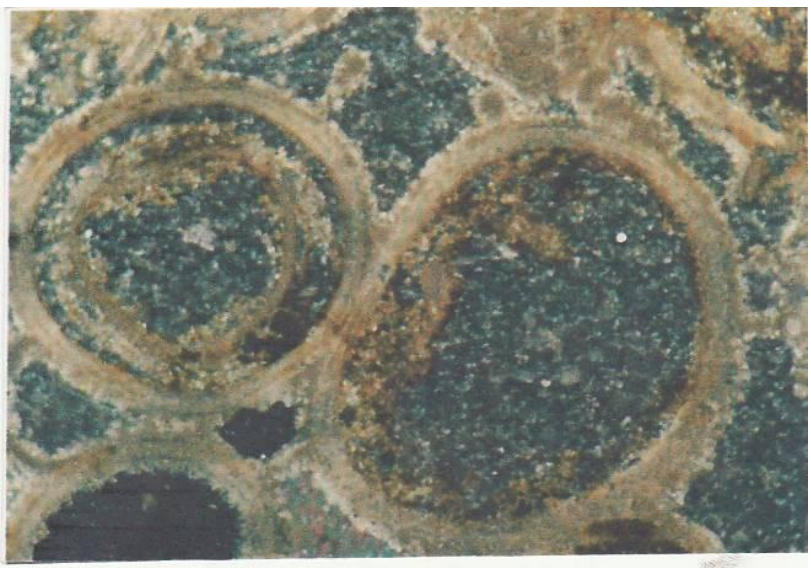

(3) Mag.x 40 packstone (plate-3 no.1\&2) with sand grains and dolomitize Oolitic grainstone (plate-3 no. $3 \& 4$ ).

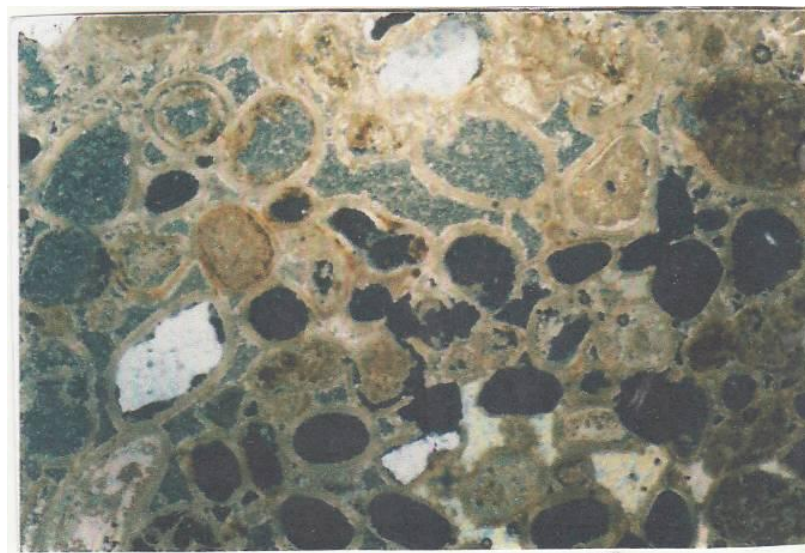

(2) Mag.x 10

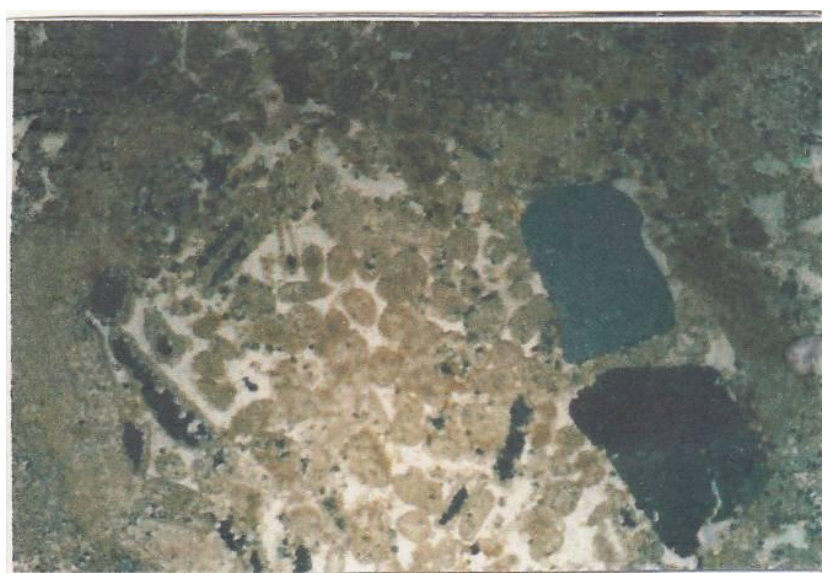

(4) Mag.x 10

\section{Plate-3 Lithfacies of Hussiniyat Formation.}

\section{5-Amij Formation:}

Consist of dolomitize Oolitic grainstone, dolomitic mudstone with thin layers of sand grains and dolomitic bioclastic wackstone (plate-9).

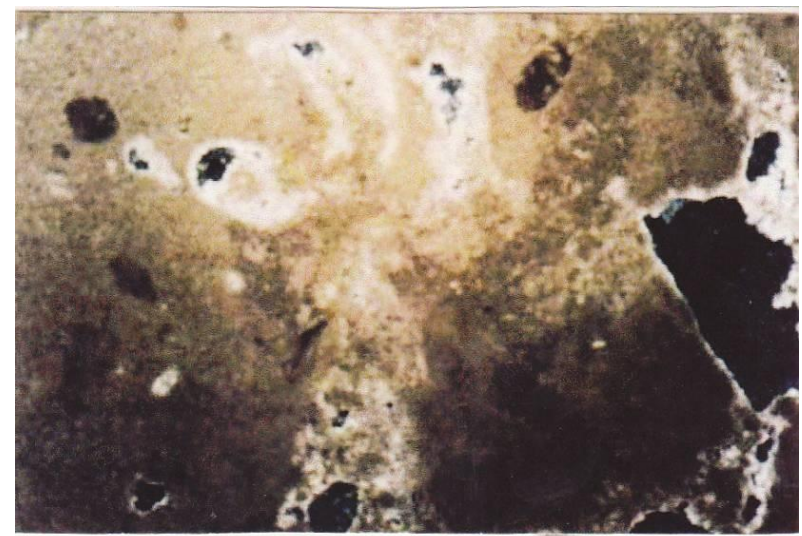

Plate-4 Lithofacies of Amij Formation Mag.x 10.
Migration pathways:

In the Mesopotamian basin migration from the late Miocene onward was directed to the west and southwest perpendicular to the depositional axis of the foredeep trend, whereas in the fold belt petroleum focused along northwest -trending compressional folds and faults systems. This west -northwest flow pattern reflects the shift in regional structural dip to the northeast that occurred in response to compressional tectonics and the developments of the Zagros orogen. Petroleum continued to migrate farther west through time as deposition expanded westward across eastern and central Iraq. The late Miocene flow-path model Fig.(6) shows that the majority of fields in the Mesopotamian basin and Zagros fold belt were located over the area 
of active source rock and on the modeled petroleum pathways by late Miocene time, thus those fields not charged before the late Miocene received a petroleum charge during and after the late Miocene, whereas the fields that were charged earlier (from the
Late Cretaceous through the middle Miocene) acquired additional charge in the late Miocene and Pliocene .In the fields that were charged earliest, the flow-path model indicates that initial petroleum generation and migration predated final entrapment by more than 60 my.
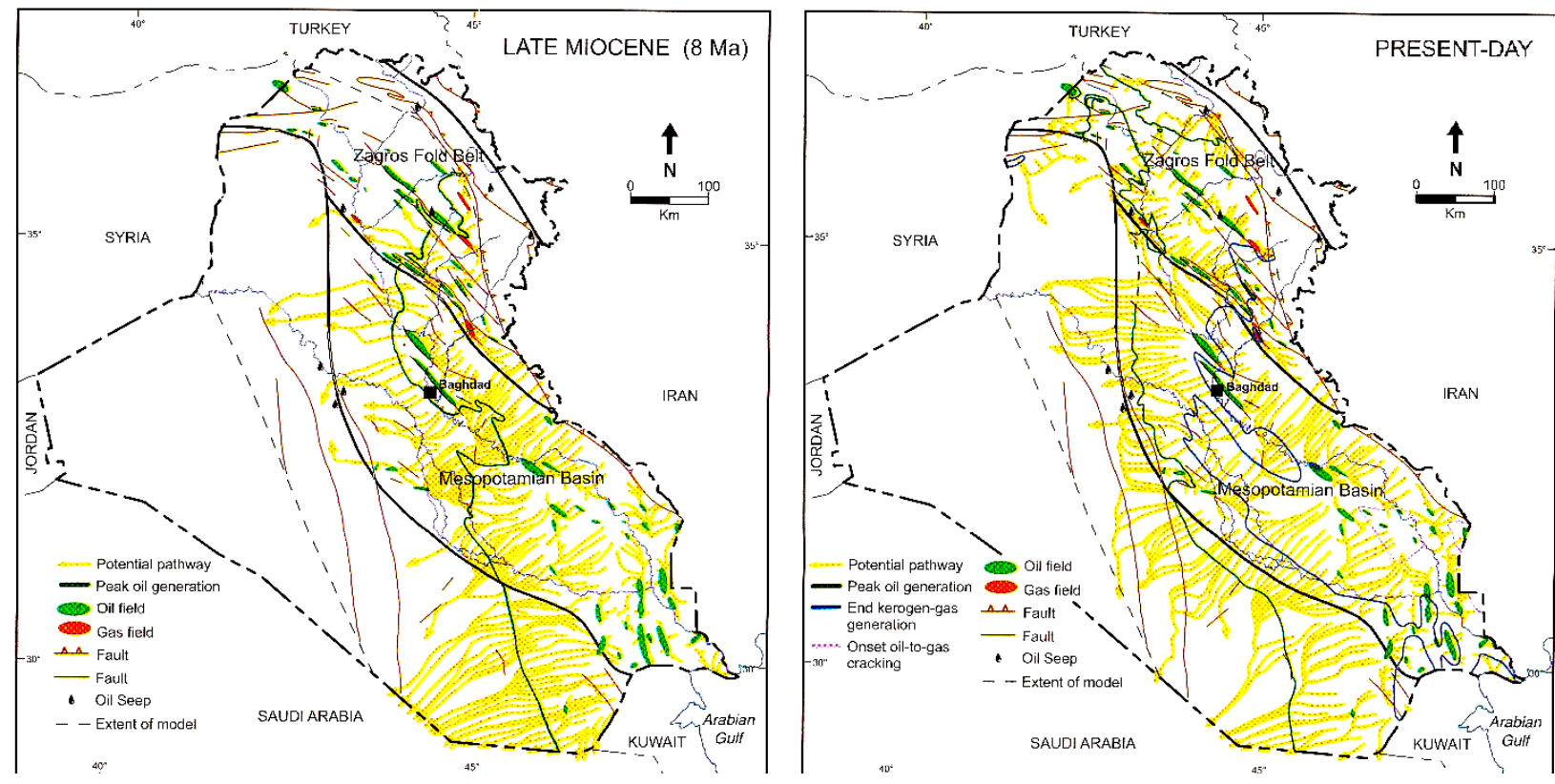

Fig.(6) Migration model (Pitman, 2004).

\section{Summary and Conclusions}

For a long time the former geologists and geochemist believes that the potentiality of generating oil and gas is focused on Cretaceous and Tertiary rocks, but reservoirs in the recent studies will going to open horizon on further correlations with the nearby region and with the surrounding countries that produce oil from Jurassic rocks, determined Jurassic rocks as the main generating of oils with subordinate gas, also it is a good reservoir. The injected oil through fault planes will permit to vertical upward migration isochronously oil pathways could permit to horizontal migration toward the typical litho and biofacies under high pressure impressed from eastern part of Iraq although the surfaces of faults could prevent it, but due to the wide extension of evaporitic and sealed layers attained to tens-hundred miles that lead to traps hydrocarbons within imbricate area .All the predications assured that the seepages of gas concentrated in the middle part of the northern regions of Iraqi lands (Qaiyarah, Makhul, Hamrin and Wadi Abu Jeer) and so many asphalt seepages situated around the area of investigation giving indication of widely and so many pathways from north and south regions of Iraq accumulated to form tremendous amounts and super giant oil and gas fields, that refers clearly to the new economic horizons, and might put Iraq in advanced ranking among the oil producing and reserving countries.

The whole prediction is relatively still sophisticated unless the efficient materials is arranged forward for more rigorous exploration processes.

\section{References}

[1] A.S. Al Sharhan, and Nairn, 1997 "Sedimentary Basins and Petroleum Geology of the Middle East", ELSEVIER P843.

[2] J.K.Pitman, D. Steinshouer, and M.D. Lewan, 2004 "Petroleum generation and migration in the Mesopotamian Basin and Zagros Fold Belt of Iraq result from a basin -modeling", vol-9 no.4, Gulf Petrolink Bahrain p.41-72. 
[3] F.H.K. Al-Jubori, 1979 "Palynological investigation in to the Bajocian (Scarborough Formation) Marine Transgression of East Yorkshire, England", $\mathrm{PhD}$ thesis, Sheffield University. (Unpublished).

[4] V.I. Ditmar, F.A. Begishev,J.T. Afanasiev, M.G.Belousova,B.A.,Brioussov,E.M.Petch eremnyh, E.I. Shmakova, and N.P. Nazarov, 1972; "Geological conditions and hydrocarbon prospects of the republic of Iraq", VII, south Iraq Int. report, INOC library, Baghdad, Iraq.

[5] J.A. Jackson, and D.P., McKenzie 1984 "Active tectonics of the Alpine Himalayan belt between western Turkey and Pakistan". Geophysical Journal of the royal astronomical society; V77, P 185 264.

[6] K. Hessami, Koyi, H.A. C.J Talbot, 2001."The significance of strike - slip faulting in the basement of the Zagros fold and thrust belt" .Journal of Petroleum Geology 24, P 5-28.

[7] J. Stocklin, 1968 " Structural history and tectonics of Iran" .Bull.AAPG, Vol.52, No.7, Tulsa.

[8] T. Buday, "Regional Geology of Iraq", Vol.1 Stratigraphy and paleontology State Organization of Minerals, Baghdad, Iraq 1980, $445 \mathrm{p}$.

[9] A.K. Jamil, and, M.A., Al-Hilaly1994. Cluster and factor analysis of geochemical data of Najmah Formation (upper Jurassic), Western Desert, Iraq. Proc. $29^{\text {th }}$ Int`l.Geol.congr .part A, pp221-236.

[10] M.A.Bassi, S.Yousif, W. Raji, H. Odisho, and L. Khalaf, 1988. Petrology, Paleontology, and geochemistry of keyhole 12/7, Western Desert of Iraq. (Internal report 1603) G.S.M.I, Baghdad, Iraq.p62.

[11] V.Bellen, R.C.Dunnington, H.V., Wetzel, R.Morten. 1959. LexiqueSratigraphique international, 0310 Asie (Iraq) 333 p reprinted by Gulf Petrol Link in 2005. (Lexique).

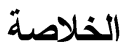

$$
\begin{aligned}
& \text { حدث نشاط تكتوني شديد خلال حركة ز اكروس } \\
& \text { (الطباشيري المتأخر -الثثلاثي المتأخر ) وكذلك النهوض } \\
& \text { الاخير الذي حصل في عصر الهولوسين، ادى الى تتشيط }
\end{aligned}
$$

بناء الطيات وأحداث فو الق وأدى ايضا الى تعرية اجز اء

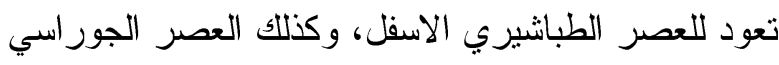
وتتابعات لأعمار جيولوجية أحدث عمر ا في غرب العراق. وضمن المنطقة المدروسة,فأن حركات الجور اسي المتقدمة مع بيئات الترسيب القديمة اوفي فترة الجور اسي الاعلى حسئ

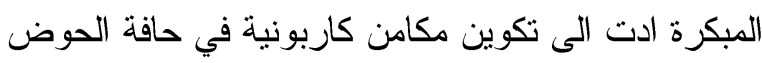
(تكوين النجمة) وصخور غطاء فعالة (تكوين القطنية)

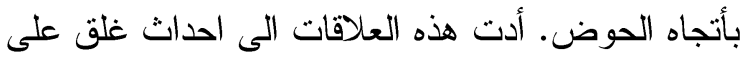
الهيروكاربونات المتولدة من تكاوين الصخور المصدرية

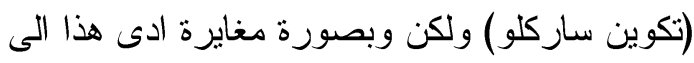
احتباس النفط المهاجر بشكل جانبي في تكوين النجمة.

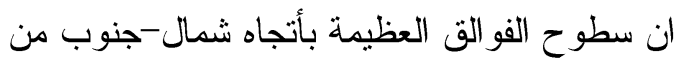

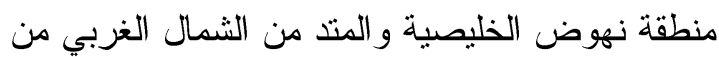
العراق الى جنوب غرب الصحراء ادى الى تكوين حواجز

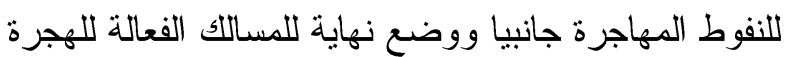
من الحوض التكويني لتكوين ساركلو في شرق وشمال شرق العراق. وفي نفس الوقت فأن النشاط الحراري المتتامي ربما ادى الى تحويل المو اد العضوية و الو اقعة في طبقات الباليوزوي (دهر الحياة القديمة) الى غاز ات ذات اتهويل

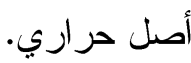
أن أجمالي النظام النفطي مكننا من الفهم الجيد لأصل

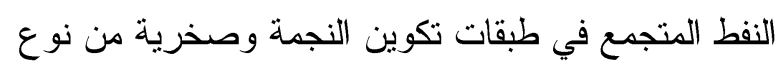
اخر ، وبالاستتاد الى المقاطع الزلز الية فانه بالامكان للنفوط

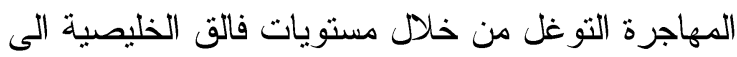
تكوين محيوير الكاربوني وهو مكافى لحوض هن تكوين ساركلو (الجور اسي المتوسط) ليكون مكمنا نفطيا فعالا تغطيه متبخر ات القطنية و انهايدر ايت العصر الكامبريجي وكذلك فأن دراسة السحنات الصخرية لتكاوين تعود للعصر الجور اسي الاسفل و المتمثل بتكاوين (عبيد، حسينيات

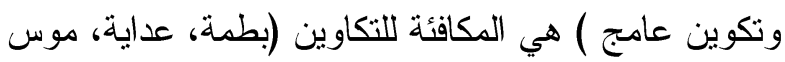

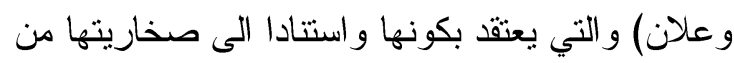
تشكيلها لمكامن نفطية جور اسية واعدة. هذا هو الاستنتاج الرئيسي من هذا البحث. ان التصور لهذا النوع من المكمن لم يتم اختباره لعدم تو افر ابار استكثافية في المنطقة. 